\title{
Determinants of Dividend Policy of Indonesian Companies: A Panel Data Analysis
}

\author{
Joshua Gorga Sijabat ${ }^{1}$, Eka Pria Anas ${ }^{2}$ \\ \{gorgajoshua@gmail.com ${ }^{1}$, ekapanas@yahoo.com² \\ Universitas Indonesia, Indonesia ${ }^{1,2}$
}

\begin{abstract}
This study aims to investigate the determinants of the dividend policy of Indonesian companies using a sample of 17 listed non-financial Indonesian companies that continuously paid dividends from 2014 to 2018 . This study uses several theories to assist readers in better comprehending the concept of dividends and dividend policy, including signaling hypothesis, free cash flow hypothesis, life cycle hypothesis, and capital structure hypothesis. This study applies a panel data analysis to test those hypotheses. The variables used in this study that may explain a company's dividend decisions are selected based on the theories and available empirical research and are determined by data availability. This study uses the dividend payout ratio and dividend yield to represent the dividend policy. The findings suggest that free cash flow, liquidity, and investment opportunity are the major determinants of the dividend payout ratio for Indonesia companies. Furthermore, the results also suggest that asset tangibility and size are major determinants of dividend yield. In general, the results apparently show little support for the signaling and capital structure hypotheses but considerable support for the free cash flow and life cycle hypotheses. This research is expected to have profound implications for future studies on dividend policy in Indonesia and might assist companies and authorities in making effective decisions about dividend policy for Indonesian companies and investors in determining their investment strategies.
\end{abstract}

Keywords: Dividend Policy, Signaling Theory, Free Cash Flow Theory, Life Cycle Theory, Capital Structure Theory

\section{Introduction}

Discussions about dividends and their relationship with the company have continued for several years. According to the most common definition, dividends are a form of corporate profit distribution to all shareholders in return for the capital they provide to the company [1]. Thus, dividend policy has a relationship with the decision to pay out company profits or retain and invest them.

Two traditional theories - signaling hypothesis and free cash flow (FCF) hypothesishave been developed to explain the company's dividend policy. Signal hypothesis states that managers, as people appointed by company owners, determine the level of dividend payments to deliver information to investors on the company's future profitability [2].

The FCF hypothesis states that dividend payments are a corporate mechanism undertaken to reduce the overinvestment problem by reducing spending on agencies that originate from FCF (agency problem). In the analysis by Jensen [3], the agency problem arises from the manager's impulse to take individual benefits, such as developing a business project by 
investing in a company's FCF, when the project has a negative value. Thus, dividend distributions are considered to reduce the risk of managers' irregular use of FCF [4].

Recently, academics developed the life cycle theory of dividends (life cycle theory). The essence of this theory is that mature, established companies are more likely to pay dividends than young companies with abundant growth opportunities and limited resources [4].

Lastly, the capital structure hypothesis explains that companies with high debt ratios are likely to face financial constraints and are less able to pay dividends, thus reducing the portion of dividends that should be distributed to shareholders [2][5].

The researchers endeavor to test the four dividend theories (signaling, FCF, life cycle, and capital structure) and various factors considered to influence dividend policies in Indonesian companies. This research draws its inspiration from a research model developed by Fairchild et al. [2] and Labhane \& Mahakud [5] for company dividend policies in Thailand and India. Researchers have observed similarities between Indonesia and Thailand, the first of which is financing that strongly depends on banks, which led to the 1998 crisis. In 2001, after the crisis, Bank Indonesia stated that bank financing at companies declined from $40 \%$ to $25 \%$ - a step taken by companies to minimize the effects of rising Indonesian interest rates [6]. In addition, ownership concentration is an issue in these two ASEAN countries. Ownership concentration on the part of the family (company founder) increases asymmetric information. Moreover, competition among families has the potential to cause company performance to deteriorate because of an inability of family members to run the company, resulting in agency conflicts between owners and investors [7].

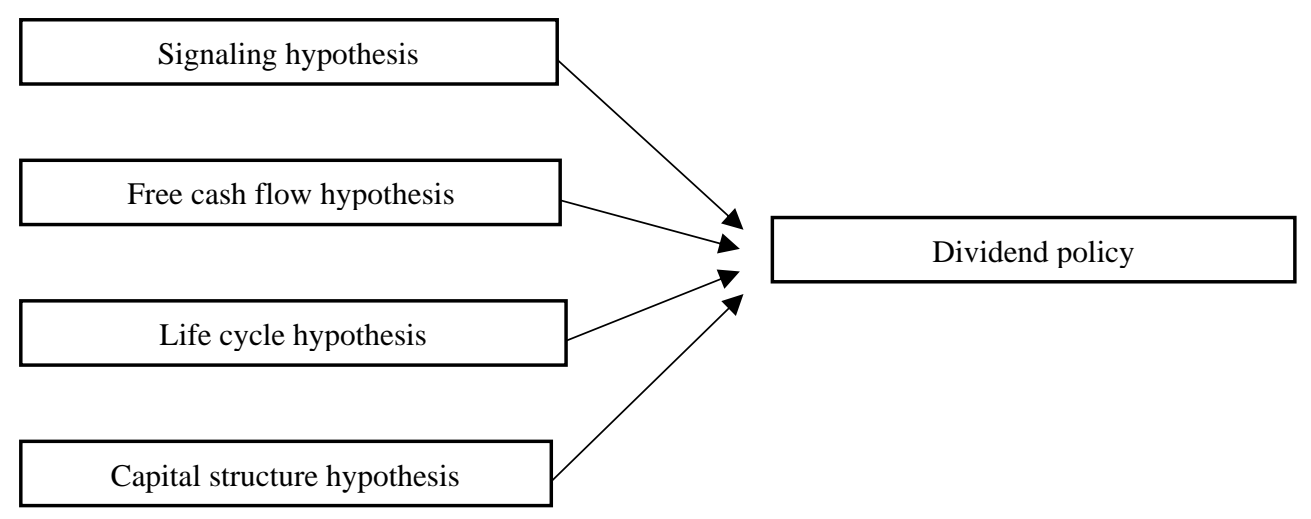

Fig. 1. The research model revealed by Fairchild et al. [2] has been further processed.

The similarities between Indonesia and India can be observed in several ways. India and Indonesia have similar characteristics in terms of poor corporate governance. The behavior of companies that are only concerned with profits has gradually created a crisis in the country, which has caused some company managers to use a dividend policy to reduce agency conflict problems between owners and outside investors [8]. In fact, an understanding of good governance standards will encourage foreign investors or multinational companies to do business with India and Indonesia.

Researchers are interested in the research model because the Indonesian investment market still presents a great opportunity. Data published by PT. Kustodian Sentral Efek Indonesia showed that the number of investors in the Indonesian capital market at the end of 2019 was 2.47 million, a figure that increased from 1.61 million in 2018 [9]. Data from the database (2019) 
showed that the highest increase was for the 18-25 age group, for which growth reached $181.01 \%$ from 2016 to 2019 . The largest number of investors was from the 41-100-year age group [10]. Moreover, investors in the over 60 age group have the largest amount of assets, approximately IDR 249.33 trillion. Based on these characteristics, Indonesian investors who have entered retirement will tend to choose to receive dividends over capital gains because of their large capital amounts and age [11].

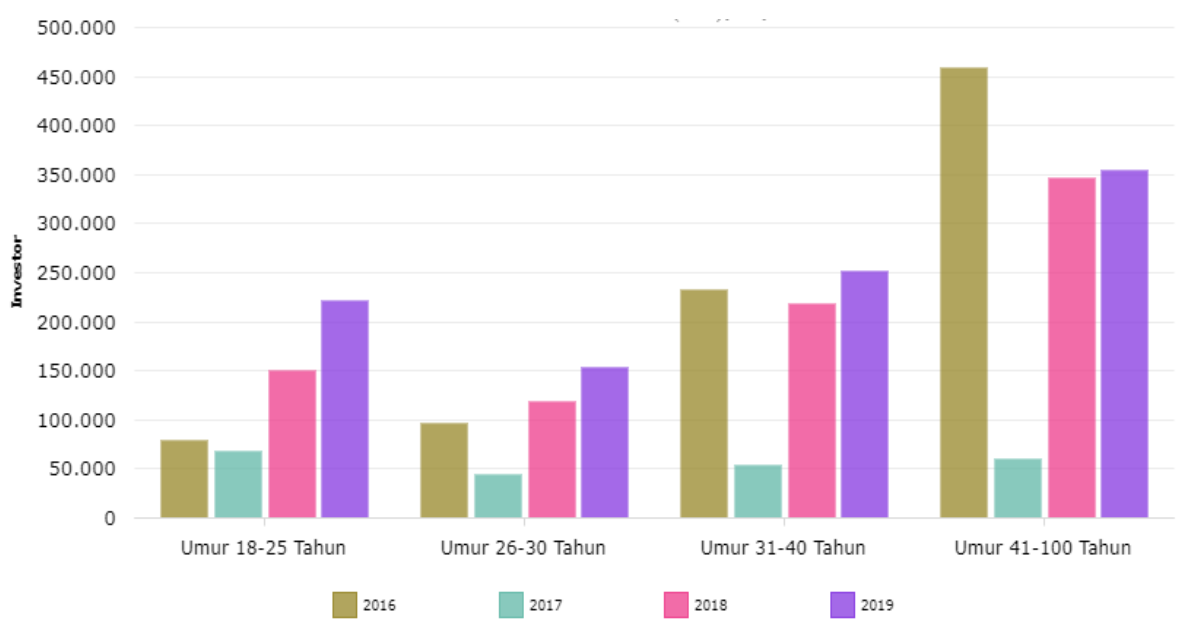

Fig. 2. The number of Indonesian investors from 2016 to 2019 is based on age group [10].

No research exists that comprehensively explained the four hypotheses, their variables, and their relationship with dividend payments in Indonesia. As a result, researchers observed a link between the FCF hypothesis and the company's life cycle hypothesis. The FCF hypothesis is represented by three variables: FCF (significantly positive), asset tangibility (significantly negative), and liquidity (significantly positive). The life cycle hypothesis is represented by two variables: investment opportunity (significantly positive) and size (significantly negative). The results show that no significant support exists for the signaling and capital structure hypotheses.

The sample of companies used is taken from the list of BEI companies that regularly pay dividends from 2014 to 2018. Dividend payment regularity is important because, if the company does not pay dividends, the data will be unbalanced. Unbalanced panel data cause problems with estimation and calculation [12].

\section{Research Methods}

Labhane and Mahakud [5] attempted to examine a number of factors that influence the level of dividend distributions using the panel data estimation method. Panel data analysis has the following advantages when paired with a cross-sectional or time series [13]:

a. More accurate model parameter interference;

b. Greater capacity to capture the complexity of human behavior;

c. Simplification of calculations and statistical inference. 
The panel data model uses two techniques to accommodate unobserved effects. First, effects that cannot be observed are included in the error. In this case, the "random effect" is the right estimator. However, problems can arise with the random effect estimators, that is, if the effects that cannot be observed are correlated with some or all of the variables. As an alternative to the random effect estimator, dummy variables can be entered for each company. This approach is commonly called the "fixed effect approach". If the researcher uses the dummy variable for only the company, then the model is called the "one-way fixed effect model". If the researcher uses the dummy variable for the company and time, then the model is known as the "two-way fixed effect model", Assuming a linear relationship between the dividend payment policy and its determinants, the panel data model can be determined as follows:

$$
Y_{i t}=\alpha+\beta_{1} B R_{i t}+\beta_{2} P R O F_{i t}+\beta_{3} F C F_{i t}+\beta_{4} T A N G_{i t}+\beta_{5} L I Q_{i t}+\beta_{6} I N V T_{i t}+\beta_{7} L C_{i t}+\beta_{8} S I Z E_{i t}+\beta_{9} L E V_{i t}+\varepsilon_{i t}
$$

Table 1. Determinants of Dividend Policy

\begin{tabular}{|c|c|c|c|}
\hline Theory & Variable & Measure & $\begin{array}{l}\text { Expected Relation } \\
\text { with Dividends }\end{array}$ \\
\hline \multirow{2}{*}{ Signaling } & $\begin{array}{l}\text { Business Risk } \\
\quad(\mathrm{BR})\end{array}$ & $\begin{array}{l}\text { measured as the standard } \\
\text { deviation of operating income } \\
\text { divided by total assets }\end{array}$ & negative \\
\hline & $\begin{array}{l}\text { Profitability } \\
\text { (PROF) }\end{array}$ & $\begin{array}{l}\text { defined as the earnings before } \\
\text { interest and taxes (EBIT) } \\
\text { divided by the total assets }\end{array}$ & positive \\
\hline \multirow{3}{*}{ Free cash flow } & $\begin{array}{l}\text { Free Cash Flow } \\
(\mathrm{FCF})\end{array}$ & $\begin{array}{l}\text { measured as the net operating } \\
\text { cash flow divided by total assets }\end{array}$ & positive \\
\hline & $\begin{array}{c}\text { Tangibility of } \\
\text { assets (TANG) }\end{array}$ & $\begin{array}{l}\text { measured as the net fixed assets } \\
\text { divided by total assets }\end{array}$ & positive \\
\hline & Liquidity (LIQ) & $\begin{array}{l}\text { defined as the ratio of current } \\
\text { assets to current liabilities }\end{array}$ & positive \\
\hline \multirow{3}{*}{ Life cycle } & $\begin{array}{l}\text { Investment } \\
\text { Opportunity } \\
\text { (INVT) }\end{array}$ & $\begin{array}{l}\text { calculated as the market value of } \\
\text { equity divided by the book value } \\
\text { of equity }\end{array}$ & negative \\
\hline & Life Cycle (LC) & $\begin{array}{l}\text { measured as the ratio of retained } \\
\text { earnings divided by total equity }\end{array}$ & positive \\
\hline & $\begin{array}{l}\text { Firm Size } \\
\text { (SIZE) }\end{array}$ & $\begin{array}{l}\text { measured as the natural } \log \text { of } \\
\text { market capitalization }\end{array}$ & positive \\
\hline $\begin{array}{l}\text { Capital } \\
\text { structure }\end{array}$ & Leverage (LEV) & $\begin{array}{l}\text { calculated as the total debt } \\
\text { divided total capital }\end{array}$ & negative \\
\hline
\end{tabular}

Where $Y_{i t}=$ dividend payout ratio (DPR) or dividend yield (DYLD) company $\mathrm{i}$ in year $\mathrm{t}$; $\mathrm{BR}_{\mathrm{it}}$ is the standard deviation of the first difference in the operating income divided by the total assets of company $\mathrm{i}$ in year $\mathrm{t}$; $\mathrm{PROF}_{\mathrm{it}}$ is a profitability variable measured as earnings before interest and taxes divided by total assets for company $i$ in year $t ; \mathrm{FCF}_{\mathrm{it}}$ is free cash flow measured as net operating cash flow divided by total assets for company $i$ in year $t$; TANG $_{i t}$ is asset tangibility measured as the ratio of net fixed assets divided by total assets for company $i$ in year $\mathrm{t}$; LIQ $\mathrm{Q}_{\text {it }}$ is liquidity measured as the current ratio, that is, current assets divided by current liabilities, for company $i$ in year $\mathrm{t}$; INVT $_{\text {it }}$ is an investment opportunity variable measured as the ratio of the market value of equity divided by the book value of equity for company $i$ in year $t$; 
$\mathrm{LC}_{\mathrm{it}}$ is the life cycle variable measured as the ratio between retained earnings and total equity for company $\mathrm{i}$ in year $\mathrm{t}$; $\mathrm{SIZE}_{\mathrm{it}}$ is a size variable measured as the natural $\log$ of the market capitalization of company $i$ in year $t ; \mathrm{LEV}_{\mathrm{it}}$ is the leverage ratio measured as the ratio of debt to capital for company $i$ in year $t ; \alpha$ is a constant; $\beta$ is the slope coefficient; and $\varepsilon_{\text {it }}$ is an error term for company $i$ in year $t$.

Researchers eliminate bank and financial services companies from the sample list because they have different accounting and regulatory practices than companies in general, and these practices significantly affect dividend payout policies. Researchers analyzed the distribution ratio of dividends in several companies that traded on the exchange from 2014 to 2018, and dividend data must be available to calculate the DPR. To be included as a sample, companies must pay dividends during the successive research period. The regularity of dividend payments becomes important because if the company does not pay dividends, then the data become unbalanced. Unbalanced panel data cause problems in estimation and calculation [12].

At the stage in which the panel data regression estimation model is determined, three approaches can be carried out, as follows:

a. Common effect model (pooled least square);

b. Fixed effect (FE) model;

c. Random effect (RE) model.

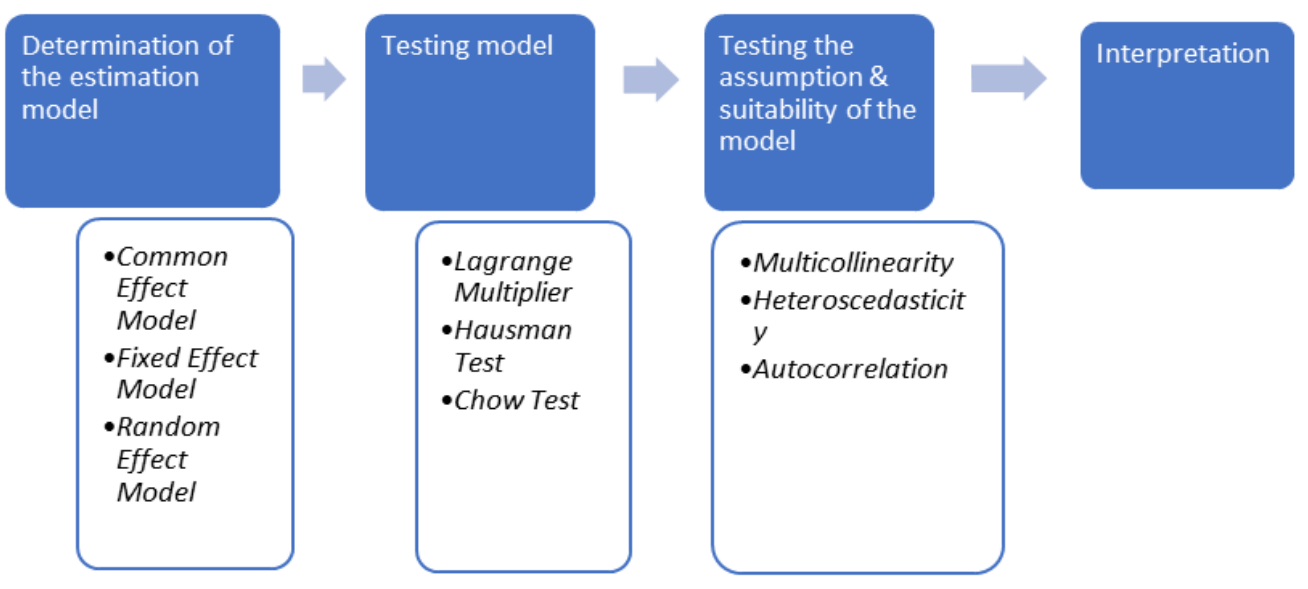

Fig. 3. Stages of Panel Data Analysis

The following three tests can be used to determine the appropriate model.

a. Lagrange multiplier (LM) test. An LM test is performed to determine whether the RE model is better than the common effect model.

H0: Common effect is a suitable model.

$\mathrm{H} 1$ : RE is a suitable model.

A p-value $<0.05$ indicates that $\mathrm{H} 0$ is rejected. 
b. Hausman test. This test aims to determine whether the FE and RE models are better than the common effect model.

H0: RE is a suitable model.

$\mathrm{H} 1$ : FE is a suitable model.

A p-value $<0.05$ indicates that $\mathrm{H} 0$ is rejected.

c. Chow test. This test is conducted to determine whether the FE regression technique is better than the common effect model. The hypotheses are as follows.

H0: Common effect is a suitable model.

$\mathrm{H} 1$ : FE is a suitable model.

A p-value $<0.05$ indicates that $\mathrm{H} 0$ is rejected.

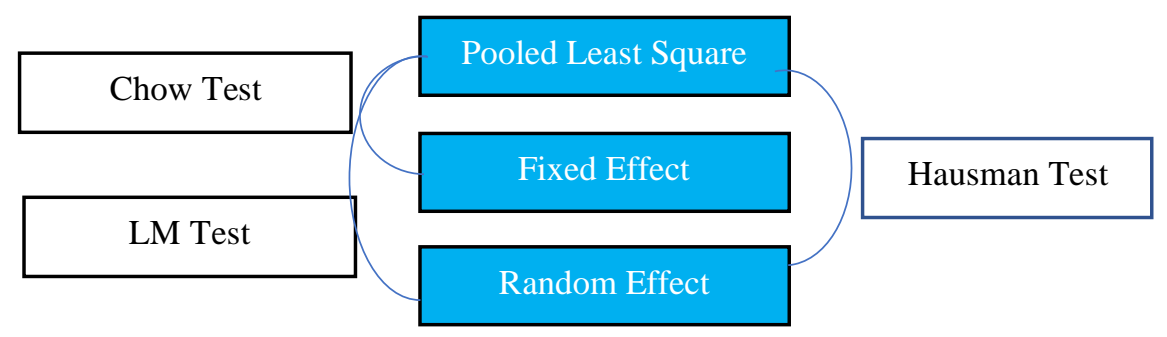

Fig. 4. Test for Each Model

After determining the right model, data processing is continued by testing the classic assumptions. The following three tests exist.

a. Multicollinearity

b. Heteroscedasticity

c. Autocorrelation

The final step after all of the steps have been taken is to interpret the data.

\section{Result and Discussion}

Table 2 presents the descriptive statistics of all of the variables in this study. The variable value of the DPR has a mean of 51.8848 and a standard deviation of 28.6229. The lowest DPR value of 0.6800 is owned by PT Multi Bintang Indonesia Tbk. (MLBI) in 2014, whereas the highest value of 145.9200 is also owned by MLBI in 2015. The DYLD variable value has a mean of 3.1224 and a standard deviation of 2.5892. DYLD value is a minimum of 0.2800 , owned by MLBI in 2018, and the maximum value is at 17.2700 , obtained by PT Indo Tambangraya Megah Tbk. in 2017. The lowest FCF variable value was -0.3370 , owned by MLBI in 2014. This negative value is derived from the company's negative net operating cash flows. 
Table 2. Descriptive Statistic

\begin{tabular}{|l|r|r|r|r|r|}
\hline Variable & \multicolumn{1}{l|}{ Mean } & \multicolumn{1}{l}{ St dev } & \multicolumn{1}{l|}{ Min } & \multicolumn{1}{l|}{ Median } & Max \\
\hline DPR & 51.8848 & 28.6229 & 0.6800 & 48.1000 & 145.9200 \\
\hline DYLD & 3.1224 & 2.5892 & 0.2800 & 2.6100 & 17.2700 \\
\hline BR & 0.0251 & 0.0319 & 0.0000 & 0.0160 & 0.2030 \\
\hline PROF & 0.1908 & 0.1568 & 0.0220 & 0.1390 & 0.6260 \\
\hline FCF & 0.0099 & 0.0798 & -0.3370 & 0.0150 & 0.2260 \\
\hline TANG & 0.4661 & 0.1237 & 0.1790 & 0.4680 & 0.6520 \\
\hline LIQ & 2.2347 & 1.7257 & 0.5140 & 1.8480 & 10.2540 \\
\hline INVT & 6.7259 & 12.4742 & 0.5250 & 2.0020 & 59.6260 \\
\hline LC & 0.7351 & 0.2341 & 0.1280 & 0.7470 & 1.0480 \\
\hline SIZE & 16.6812 & 1.6594 & 13.5160 & 16.6650 & 19.8710 \\
\hline LEV & 0.1639 & 0.1439 & 0.0000 & 0.1150 & 0.5750 \\
\hline
\end{tabular}

Table 3. Correlation between Variables

\begin{tabular}{|c|c|c|c|c|c|c|c|c|c|c|}
\hline & DPR & BR & PROF & FCF & TANG & LIQ & INVT & LC & SIZE & LEV \\
\hline DPR & 1 & & & & & & & & & \\
\hline BR & 0.2611 & 1 & & & & & & & & \\
\hline PROF & 0.3558 & 0.4883 & 1 & & & & & & & \\
\hline FCF & 0.2133 & 0.052 & -0.0029 & 1 & & & & & & \\
\hline TANG & -0.0899 & 0.2038 & 0.0053 & -0.1093 & 1 & & & & & \\
\hline LIQ & 0.226 & -0.2074 & -0.0471 & -0.0464 & -0.4136 & 1 & & & & \\
\hline INVT & 0.2822 & 0.3891 & $0.8184^{*}$ & -0.1971 & 0.2557 & -0.2562 & 1 & & & \\
\hline LC & -0.0681 & 0.2383 & 0.2608 & -0.0009 & -0.1061 & -0.5319 & 0.3364 & 1 & & \\
\hline SIZE & 0.0721 & 0.0457 & 0.3329 & 0.0336 & 0.1921 & -0.2414 & 0.4463 & 0.112 & 1 & \\
\hline LEV & -0.0719 & 0.1551 & 0.065 & -0.1941 & 0.4936 & -0.5356 & 0.3557 & 0.2686 & 0.4155 & 1 \\
\hline
\end{tabular}

\begin{tabular}{|c|c|c|c|c|c|c|c|c|c|c|}
\hline & DYLD & BR & PROF & FCF & TANG & LIQ & INVT & LC & SIZE & LEV \\
\hline DYLD & 1 & & & & & & & & & \\
\hline BR & 0.1654 & 1 & & & & & & & & \\
\hline PROF & 0.0252 & 0.4883 & 1 & & & & & & & \\
\hline FCF & 0.1782 & 0.052 & -0.0029 & 1 & & & & & & \\
\hline TANG & -0.1129 & 0.2038 & 0.0053 & -0.1093 & 1 & & & & & \\
\hline LIQ & 0.1554 & -0.2074 & -0.0471 & -0.0464 & -0.4136 & 1 & & & & \\
\hline INVT & -0.1615 & 0.3891 & $0.8184 *$ & -0.1971 & 0.2557 & -0.2562 & 1 & & & \\
\hline LC & -0.1981 & 0.2383 & 0.2608 & -0.0009 & -0.1061 & -0.5319 & 0.3364 & 1 & & \\
\hline SIZE & -0.1666 & 0.0457 & 0.3329 & 0.0336 & 0.1921 & -0.2414 & 0.4463 & 0.112 & 1 & \\
\hline LEV & -0.2807 & 0.1551 & 0.065 & -0.1941 & 0.4936 & -0.5356 & 0.3557 & 0.2686 & 0.4155 & 1 \\
\hline
\end{tabular}

Table 3 represents the correlations of the independent variable, and a correlation between the profitability (PROF) and investment opportunity (INVT) variables exists. This correlation may occur because greater opportunities (for the company) exist to invest as profits increase. However, according to Haron [14], because the correlation value is lower than 0.95 , the collinearity of the variables does not matter. Therefore, all independent variables can be included in the regression. 
Table 4. Summary of the Determinants of Dividend Payout Ratio dan Dividend Yield

\begin{tabular}{|c|c|c|}
\hline & DPR & DYLD \\
\hline \multirow[t]{2}{*}{$\mathrm{BR}$} & 183.8867 & 12.9737 \\
\hline & $(158.0945)$ & $(17.5224)$ \\
\hline \multirow[t]{2}{*}{ PROF } & -12.0948 & 2.9167 \\
\hline & $(54.2351)$ & $(3.8301)$ \\
\hline \multirow[t]{2}{*}{ FCF } & $112.0323 * *$ & 3.8915 \\
\hline & $(55.6387)$ & $(3.1614)$ \\
\hline \multirow[t]{2}{*}{ TANG } & -29.9951 & $-4.3305 *$ \\
\hline & $(28.7615)$ & $(2.6084)$ \\
\hline \multirow[t]{2}{*}{ LIQ } & $5.1870 * * *$ & 0.0895 \\
\hline & $(1.8019)$ & $(0.3059)$ \\
\hline \multirow[t]{2}{*}{ INVT } & $1.0714 *$ & -0.008 \\
\hline & $(0.5957)$ & $(0.0552)$ \\
\hline \multirow[t]{2}{*}{$\mathrm{LC}$} & -14.6387 & -2.4069 \\
\hline & $(14.8965)$ & $(3.3336)$ \\
\hline \multirow[t]{2}{*}{ SIZE } & -0.9323 & $-0.4655 * *$ \\
\hline & $(2.0238)$ & $(0.1832)$ \\
\hline \multirow[t]{2}{*}{ LEV } & 16.1524 & 0.8045 \\
\hline & $(30.3366)$ & $(3.6989)$ \\
\hline \multirow[t]{2}{*}{ cons } & $67.3173 *$ & $13.4772 * *$ \\
\hline & $(38.1095)$ & $(6.2611)$ \\
\hline$N$ & 85 & 85 \\
\hline $\operatorname{adj.} R^{2}$ & 0.2260 & 0.0930 \\
\hline$R^{2}$ & 0.3091 & 0.1253 \\
\hline LM test & 0.1147 & 0.0000 \\
\hline Hausman test & 0.9327 & 0.3727 \\
\hline Chow test & 0.7825 & 0.0000 \\
\hline VIF & 2.5800 & 2.5800 \\
\hline Wald Test & 0.0000 & 0.0000 \\
\hline Wooldridge Test & 0.8392 & 0.1410 \\
\hline
\end{tabular}

Standard errors in parentheses

$* p<0.1, * * p<0.05, * * * p<0.01$

The determination of the most suitable model, namely, among PLS, FE, and RE, uses three testing stages. The first test conducted was the LM test to choose between PLS and RE. The second test is the Hausman test to choose between the FE and RE models. The final test is the Chow test to ascertain which of the PLS and FE models is the correct one.

The regression results are listed in Table 4, for which the PLS estimation model is used for the DPR variable, and the RE model is used for the DYLD variable. 
For the DPR variable, the results of the LM test state that the PLS model is more appropriate than the RE model for a p-value $>0.05$, such that $\mathrm{H} 0$ is not rejected. The Hausman test results show that the RE model is suitable because the p-value $>0.05$, and $\mathrm{H} 0$ is not rejected. The Chow test results state that the PLS model is suitable because the p-value $>0.05$, and $\mathrm{H} 0$ is accepted. In conclusion, the PLS model is used for the research.

For the DYLD variable, the results of the LM test state that the RE model is more appropriate to use because the p-value $<0.05$, and H0 is rejected. Hausman test results show that the RE model is more suitable than the FE because the p-value $>0.05$, and $\mathrm{H} 0$ is not rejected. The result of the correct Chow test model is FE because the p-value < 0.05 ; then, $\mathrm{H} 0$ is rejected. In conclusion, RE is the appropriate model to use.

Based on data from the table, no multicollinearity problem exists with the DPR or DYLD variables because the value of the variance inflation factor is less than 10 [5].

The heteroscedasticity test is next, which is conducted using the Wald test. Table 4 indicates that both the DPR and DYLD variables have a heteroscedasticity problem because the p-value $<0.05$. Heteroscedasticity usually occurs with cross-section data, for which panel data are closer to the characteristics of the data section than time series data. However, if the heteroscedasticity assumption is not met, then the regression model can be considered invalid as an estimation model, which can be corrected using FGLS regression. After the FGLS regression, the results show that the data include homoscedasticity such that heteroscedasticity problems do not occur.

The last class assumption test conducted was to measure autocorrelation using the Wooldridge test. The results show a p-value $>0.05$, indicating that the autocorrelation problem did not occur.

The R square results indicate that the independent variable can explain $30.91 \%$ of the DPR variable. Meanwhile, the independent variable only explained $12.53 \%$ of the DYLD variable. That is, many other influencing factors exist that are external to the model.

The PLS results show that the FCF, liquidity (LIQ), and investment opportunity (INVT) variables significantly affect the DPR variable. In accordance with the theory, FCF has a positive relationship with the DPR at the $5 \%$ level. These results are consistent with Labhane \& Mahakud [5] and Jensen \& Meckling [3]. Companies that generate more FCF can distribute more dividends to shareholders [5]. The same phenomenon also happened to the liquidity variable, which was positively correlated and in accordance with the initial hypothesis at the $1 \%$ level. These values are in line with theories written by Labhane \& Mahakud [5] and Rój [1]. A higher liquidity ratio then shows relatively smaller debt compared with assets; therefore, the possibility of paying higher dividends is even greater [5]. However, investment opportunities are positively correlated with the DPR, which is not in accordance with the initial hypothesis at the $10 \%$ level. This finding is in line with Rój [1], who measured the effect of several variables on dividend payouts in Poland. Rój stated that despite having high investment opportunities, companies in Poland still had sufficient cash to pay dividends. This phenomenon may exist because Poland and Indonesia are still in developing markets, and the theories that apply to developed countries may not necessarily be in accordance with developing countries [1].

The results of the RE model show that asset tangibility (TANG) and company size (SIZE) are the variables that have a significant effect on the DYLD variables. Unlike the initial hypothesis, both are negatively correlated with dividend yield. These results are significant at the $10 \%$ level, which occurs for TANG, according to the research by Labhane and Mahakud [5] and Aivazian et al. [15]. This result is possible if companies that have many fixed assets in developing countries sometimes experience financial difficulties from the unavailability of short-term financing to cover working capital needs [5]. The results of the correlation are 
negative and significant at the 5\% level for firm size variables, which is not in line with the research of Labhane \& Mahakud [5] and Rój [1]. This finding indicates that small companies tend to pay even higher dividends. According to Zhang \& Fu [16], these results are because of the characteristics of market capitalization in developing countries, the majority of which are small relative to global companies.

\section{Conclusion}

As a result, researchers observe a significant lack of support for the signal hypothesis and a capital structure with a dividend policy. In contrast, researchers observe a relationship between the FCF hypothesis and the life cycle. The FCF hypothesis is represented by three variables: FCF (significantly positive), asset tangibility (significantly negative), and liquidity (significantly positive). The life cycle hypothesis is represented by two variables: investment opportunity (significantly positive) and size (significantly negative).

In conclusion, the effect of the FCF hypothesis on dividend policy is supported by Fairchild et al. [2]; Labhane \& Mahakud [5]; Bostanci et al. [17]; and Smith \& Pennathur [18], whereas the influence of the company's life cycle hypothesis on dividend policy is supported by Fairchild et al. [2]; Labhane \& Mahakud [5]; El-Ansary \& Gomaa [19]; and Hassani \& Dizaji [20].

Researchers' first suggestion for further research is to try other variables outside of those covered in this study. Thus, it is expected that the R-square value will increase and make the research model more descriptive of the various factors that influence the dividend policy of Indonesian companies as a whole. One variable that can be considered is the share ownership of the board of directors (directors and commissioners). It is expected that the increasing number of shares owned by the directors will also increase the company's dividend payments due to agency problems. In addition, it would be better if the research further investigated by separating the categories based on stand-alone companies and companies that are in a group (corporations). This is expected to affect dividend policy because corporations are more likely to hold back the parent company's profit and distribute them to its subsidiaries that need additional capital. Another variable that can be further elaborated on is the companies' life cycle stages. The second suggestion is to increase the research period, so that researchers can discuss trends in dividend policy in Indonesia.

Table 5. Results Summary

\begin{tabular}{|c|c|c|c|c|}
\hline \multirow{2}{*}{ Theory } & Variable & Expected & Result & $\begin{array}{c}\text { Level of } \\
\text { Significance }\end{array}$ \\
\hline \multirow{2}{*}{$\begin{array}{c}\text { Free Cash } \\
\text { Flow }\end{array}$} & Free Cash Flow & positive & positive & $5 \%$ \\
\cline { 2 - 5 } & Tangibility of Assets & positive & negative & $10 \%$ \\
\cline { 2 - 5 } Life Cycle & Liquidity & positive & positive & $1 \%$ \\
\cline { 2 - 5 } & Investment Opportunity & negative & positive & $10 \%$ \\
\hline \multirow{2}{*}{ Size } & positive & negative & $5 \%$ \\
\hline
\end{tabular}

A summary of the final results shows that the theory that affects the company's dividend policy in Indonesia is the theory of FCF and the life cycle theory of the company. The effect of the FCF theory on dividend policy is supported by Fairchild et al. [2]; Labhane \& Mahakud [5]; Bostanci et al. [17]; and Smith \& Pennathur [18]. FCF is generally used as a relatively 
appropriate benchmark to understand the state of the company because this component is more difficult to manipulate. Investors use the theory of FCF to determine how efficient a company is with its use of cash and to determine whether the company has enough cash to pay dividends.

The application of the company's life cycle theory to dividend policy is supported by Fairchild et al. [2]; Labhane \& Mahakud [5]; El-Ansary \& Gomaa [19]; and Hassani \& Dizaji [20]. Companies that are still in the developing stage will invest large amounts of money, forcing them to increase their sources of capital from external financing. As a result, companies will skimp, possibly by not paying dividends. Mature companies have stable profits and investment opportunities, encouraging companies to subsequently distribute profits in the form of dividends.

\section{References}

[1] J. Rój, "The Determinants of Corporate Dividend Policy in Poland," Ekonomika, vol. 98, no. 1, pp. 96-110, 2019.

[2] R. Fairchild, Y. Guney, and Y. Thanatawee, "Corporate dividend policy in Thailand: Theory and evidence," Int. Rev. Financ. Anal., vol. 31, pp. 129-151, 2014.

[3] M. C. Jensen and W. H. Meckling, "Theory Of The Firm: Managerial Behavior, Agency Costs And Ownership Structure," J. financ. econ., vol. 3, pp. 305-360, 1976.

[4] H. K. Baker and R. Weigand, "Corporate dividend policy revisited," Manag. Financ., 2015.

[5] N. B. Labhane and J. Mahakud, "Determinants of dividend policy of Indian companies: A panel data analysis," Paradigm, vol. 20, no. 1, pp. 36-55, 2016.

[6] J. Agung, B. Kusmiarso, B. Pramono, E. G. Hutapea, A. Prasmuko, and N. J. Prastowo, "Credit crunch in Indonesia in the aftermath of the crisis: Facts, causes and policy implications," 2001.

[7] M. Bambang and M. Hermawan, "Founding family ownership and firm performance in consumer goods industry: Evidence from Indonesia," Available SSRN 2292375, 2013.

[8] R. Kulkani and B. Maniam, "Corporate Governance--Indian Perspective," Int. J. Trade, Econ. Financ., vol. 5, no. 4, p. 364, 2014.

[9] M. Wareza, "Hari Terakhir Bursa 2019, Investor Pasar Modal Capai 2,4 Juta," CNBC Indonesia, 2019. [Online]. Available: https://www.cnbcindonesia.com/market/20191230142312-17126472/hari-terakhir-bursa-2019-investor-pasar-modal-capai-24-juta.

[10] D. H. Jayani, “Tren Investor Milenial di Pasar Modal Terus Meningkat,” Databoks, 2019. [Online]. Available: https://databoks.katadata.co.id/datapublish/2019/10/31/tren-investormilenial-selalu-meningkat\#.

[11] Arum, "Dividen dan Capital Gain-Business Lounge," Business Lounge Journal, 2013. [Online]. Available: https://www.blj.co.id/2013/08/14/dividen-dan-capital-gain/.

[12] H. M. Park, "Practical guides to panel data modeling: a step-by-step analysis using stata," Public Manag. Policy Anal. Program, Grad. Sch. Int. Relations, Int. Univ. Japan, vol. 12, pp. 1-52, 2011.

[13] C. Hsiao, "Panel data analysis—advantages and challenges," Test, vol. 16, no. 1, pp. 1-22, 2007.

[14] R. Haron, "Do Indonesian firms practice target capital structure? A dynamic approach," J. Asia Bus. Stud., 2016.

[15] V. Aivazian, L. Booth, and S. Cleary, "Do Firms in Emerging Markets Follow Different Dividend Policies From Those in the US: Evidence From Firms in Eight Emerging Countries," J. Financ. Res., vol. 26, no. 3, pp. 175-188, 2001.

[16] X. Zhang and J. Fu, "Does ownership structure matter for dividend yield? Evidence from the Hong Kong stock exchange,” Bus. Econ. Res., vol. 4, no. 2, pp. 204-221, 2014.

[17] F. Bostanci, E. Kadioglu, and G. Sayilgan, "Determinants of dividend payout decisions: a dynamic panel data analysis of Turkish stock market," Int. J. Financ. Stud., vol. 6, no. 4, p. 93, 2018.

[18] D. D. Smith and A. K. Pennathur, "Signaling Versus Free Cash Flow Theory: What Does Earnings Management Reveal About Dividend Initiation?,” J. Accounting, Audit. Financ., vol. 
34, no. 2, pp. 284-308, 2019.

[19] O. El-Ansary and T. Gomaa, "The life cycle theory of dividends: Evidence from Egypt," Int. Res. J. Financ. Econ., vol. 97, pp. 72-80, 2012.

[20] M. Hassani and F. Dizaji, "Life cycle theory and dividend payout policy: Evidence from Tehran Stock Exchange," Manag. Sci. Lett., vol. 3, no. 10, pp. 2631-2634, 2013. 